\title{
Ill Effects of Technology: Dehiscence Encountered Following Laser Depigmentation: A Case Report
}

\author{
Anamika Sharma ${ }^{1 *}$ and Sharma Vishal ${ }^{2}$ \\ ${ }^{1}$ Department of Periodontology, Subharti Dental College SVSU, India \\ ${ }^{2}$ Private Practitioner, India
}

Submission: September 10, 2018; Published: October 09, 2018

*Corresponding author: Anamika Sharma, 98-Rajan Kunj, Roorkee Road, Meerut-250003, India, Tel: +91 9219600994;

Email: prof_anamika@hotmail.com

\begin{abstract}
Deformities of the alveolar process discovered during mucogingival procedures can present surgical dilemmas which may seriously affect the outcome of treatment Fenestration and dehiscence are localized defects of the cortical bone which covers the teeth. Etiologic factors include developmental anomalies, frenum attachments, orthodontic tooth movement, periodontal and endodontic pathosis, trauma from occlusion, tooth size, and tooth position. The present report describes a case of alveolar dehiscence in relation to maxillary canine encountered three months following diode laser depigmentation
\end{abstract}

Keywords: Pathosis; Trauma; Cortical bone; Deformities; Etiologic

\section{Introduction}

An alveolar dehiscence denotes a lack of the facial or lingual alveolar cortical plate resulting in a denuded root surface, while an alveolar fenestration is a circumscribed defect of the cortical plate which exposes the underlying root surface, not involving the marginal bone [1]. Deformities of the alveolar process can present surgical dilemmas which are technically demanding and may seriously affect the outcome of treatment [2]. The overall prevalence ranges from 0.99 to $13.4 \%$ for dehiscences and $0.23 \%$ to $16.9 \%$ for fenestrations. Elliott \& Bowers [3] reported that alveolar dehiscences and fenestrations were associated with $9.19 \%$ and $10.93 \%$, respectively.

\section{Case Report}

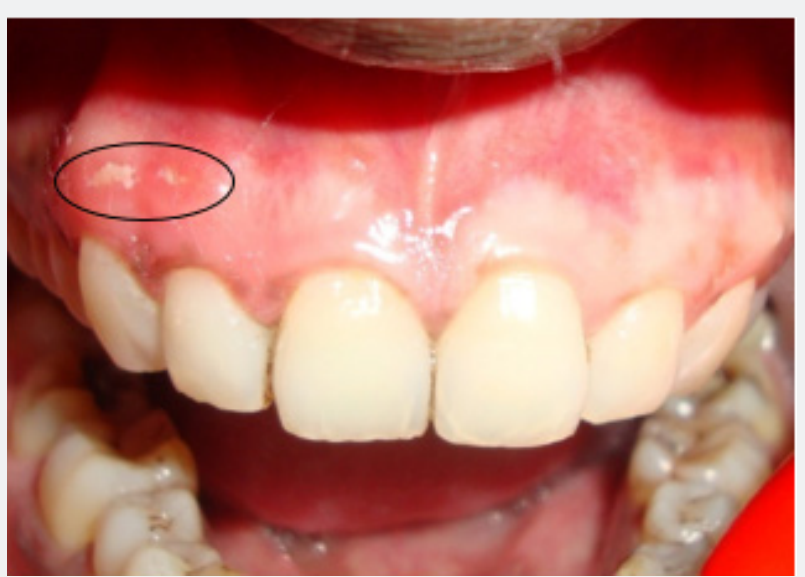

Figure 1: Preoperative.

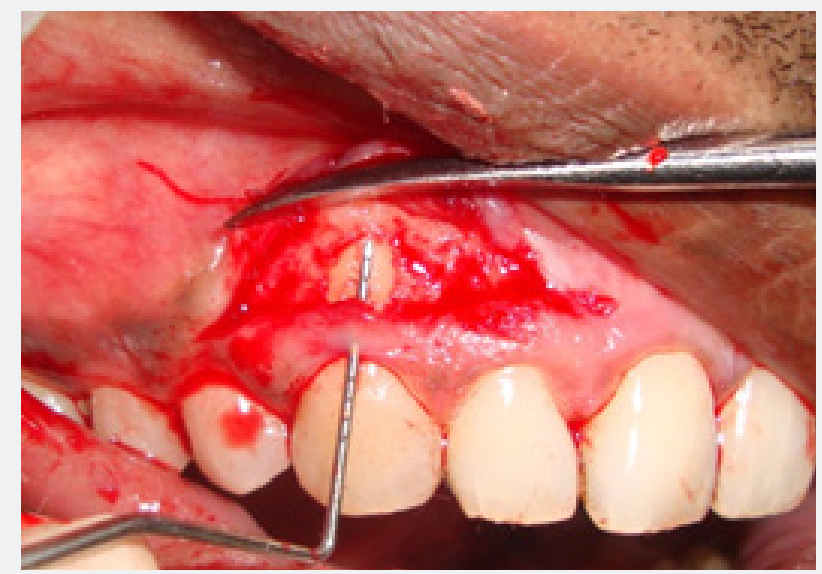

Figure 2: Alveolar Dehiscence Seen on Flap Reflection.

A 25-year-old male patient reported with the complaint of dark colored gums. Gingival depigmentation was performed with diode laser in both maxillary and mandibular arches in the intercanine region. Three months postoperatively, the patient reported with pain in the attached gingiva of the maxillary right lateral incisor and canine. On examination, a bony sequestrum surrounded by erythema was observed in the gingiva overlying the maxillary right lateral incisor and canine (Figure 1). A sub marginal incision was given with a 15 no.B.P.blade in the attached gingiva extending from the maxillary right lateral incisor to the maxillary right first premolar. A full thickness flap was reflected to perform alveoloplasty for removal of the bony sequestrum and reshaping of the underlying bone. On removal of the sequestrum, an alveolar dehiscence was found in relation to the maxillary right 
canine, measuring up to $6 \mathrm{~mm}$ from the gingival margin (Figure 2). Alveoloplasty was performed; the flap was repositioned and sutured with 5-0 black silk and postoperative instructions given (Figure 3). Antibiotic and analgesic were prescribed for 5 days. Erythema was absent one week postoperatively, but slight pain was reported (Figure 4). On one month follow up, the gingiva was pink, firm and resilient with stippled appearance and absence of pain (Figure 5).

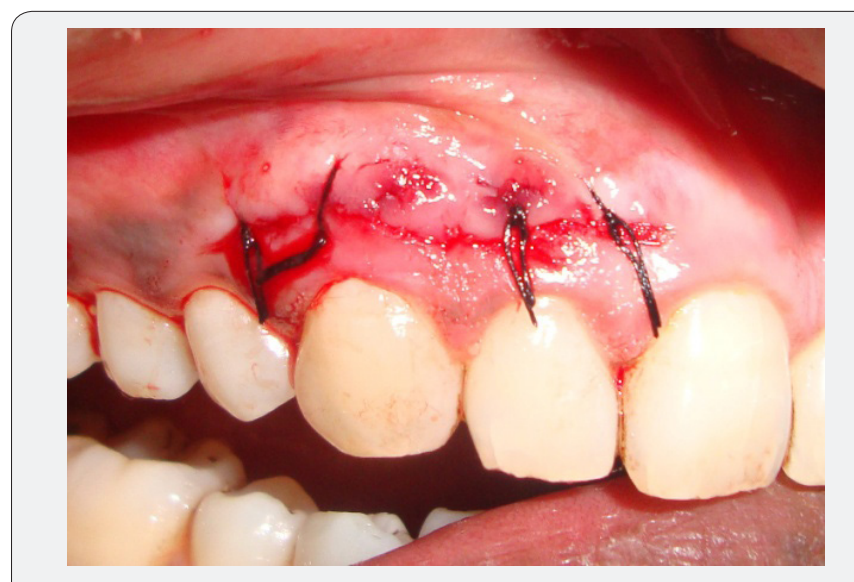

Figure 3: Sutures Placed.

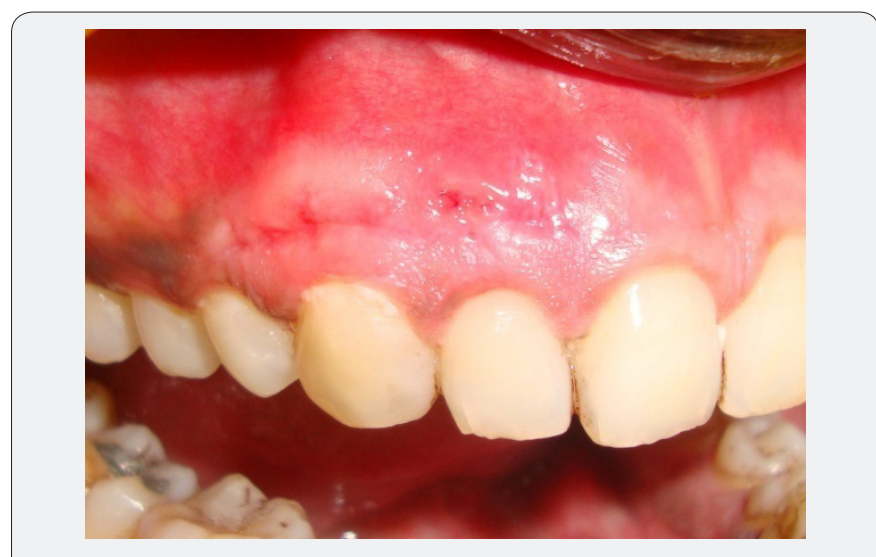

Figure 4: 1 Week Postoperative.

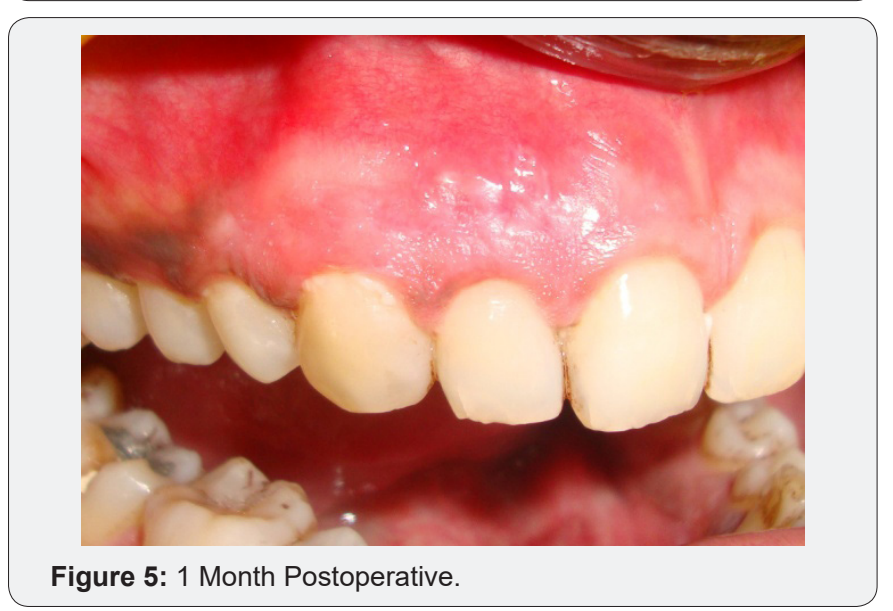

\section{Discussion}

Alveolar bone architecture may vary from patient to patient in point of thickness, contour and configuration, and all these variations may be both normal and healthy1. The cause of these differences is the unique dependence between the morphology of the alveolar process and the teeth. The bone contour normally conforms to the prominence of the roots with intervening vertical depressions that taper toward the margin [4]. Previous studies have reported the prevalence of alveolar dehiscences and fenestrations in human skulls and autopsy specimens from a variety of populations including Japanese [4], Bedouins [5], Italians \& Australians [6], Mexican Indians [7], Egyptians [1], Britons [8] and South African Blacks [9]. Clinical predictors of dehiscences and fenestrations have not been well defined.

A number of possible etiologic factors have been examined, including developmental anomalies, frenum attachments, orthodontic tooth movement, periodontal and endodontic pathosis, trauma from occlusion, tooth size, and tooth position [2]. Davies et al [8] found dehiscences and fenestrations in 5.36\% and $8.45 \%$ in teeth of 398 nineteenth century British skulls. Dehiscences were most commonly associated with mandibular canines and first premolars and maxillary canines and first molars. Fenestrations were most frequently associated with maxillary first molars. Edel [6] evaluated 87 dry Bedouin jaws and found the prevalence of dehiscences and fenestrations to be $4.40 \%$ and $9.70 \%$, respectively, in 990 teeth examined. Our patient presented a dehiscence in the maxillary canine. Possible etiologic factor for the existence of this defect may be the prominent root of canine in combination with a thin alveolar bone plate. This observation is consistent with previous reports by Abdelmalek et al. [1] \& Edel [6].

Presence of the alveolar defect observed in our patient may also be attributed to the use of laser beam deep into the connective tissue in an attempt to remove the pigmented tissues completely. Also the soft tissues overlying the canine region are thin, therefore laser ablation may have been inadvertently carried out in close proximity of bone, leading to necrosis and eventually sequestration of bone. Similar findings were reported by Atsawasuwan et al. [10] in 4 cases of gingival pigmentation treated with Nd:YAG laser. Lost [11] reported that in most cases the bone crest was found to be about $3 \mathrm{~mm}$ from the position of the gingival margin; however, in $14 \%$ of instances, the bone crest was observed located more than $4 \mathrm{~mm}$ from the position of the pre-surgical soft tissue margin, most often associated with mandibular canines. Similarly, in our patient, the distance of crestal bone from gingival margin was 6 $\mathrm{mm}$, though no recession was present over the canine.

Clinically, the intraoperative discovery of an alveolar dehiscence or fenestration requires special consideration. If a defect is unintentionally exposed, root instrumentation which may remove radicular connective tissue fibers should be avoided, the root surface should not be permitted to become desiccated, and soft tissue coverage of the defect must be ensured. The soft tissue used to cover these defects, whether obtained by use of a free autogenous graft or mobilized soft tissue flap, must have an adequate blood supply to overcome the lack of perfusion from the avascular root surface. The absence of crestal bone reduces 
support for the soft tissue flap and may increase the likelihood of undesirable post-operative gingival recession. Flaps must be carefully positioned and sutured to optimally support the flap margin in the desired position [2].

\section{Conclusion}

Alveolar dehiscence is a defect which may be encountered over the maxillary canine as an intraoperative discovery. Possible etiologic factors include malpositioned tooth with thin alveolar bone which may undergo necrosis and eventually sequestration of bone by laser ablation carried deep into connective tissue.

\section{References}

1. Abdelmalek RG, Bissada NF (1973) Incidence and Distribution of Alveolar Bone Dehiscence and Fenestration in Dry Human Egyptian Jaws. J Periodontol 44(9): 586-588.

2. Rupprecht RD, Horning GM, Nicoll BK, Cohen ME (2001) Prevalence of Dehiscences and Fenestrations in Modern American Skulls. J Periodontol 72(6): 722-729.

3. Elliott JR, Bowers GM (1963) Alveolar Dehiscence and Fenestration. Periodontics 1: 245-248.
4. Nimigean VR, Nimigean V, Bencze MA, Dimcevici-Poesina N, Cergan R, et al. (2009) Alveolar Bone Dehiscences and Fenestrations: an Anatomical Study and Review. Rom J Morphol Embryol 50(3): 391397.

5. Ezawa T, Sano H, Kaneko K, Huruma S, Fufikawa K, et al. (1987) The Correlation between the Presence of Dehiscence or Fenestration and the Severity of Tooth Attrition In Contemporary Dry Japanese Adult Skulls. J Nihon Univ Sch Dent 29(1): 27-34.

6. Edel A (1981) Alveolar Bone Fenestrations and Dehiscences in Dry Bedouin Jaws. J Clin Periodontol 8(6): 491-499.

7. Larato DC (1970) Alveolar Plate Fenestrations and Dehiscences of Human Skull. Oral Surg Oral Med Oral Pathol 29(6): 816-819.

8. Davies RM, Downer MC, Hull PS, Lennon MA (1974) Alveolar Defects in Human Skulls. J Clin Periodontol 1(2): 107-111.

9. Tal H (1983) Alveolar Dehiscence and Fenestrae in Dried South African Negro Mandibles. Am J Phys Anthropol 61(2): 173-179.

10. Atsawasuwan P, Greethong K, Nimmanon V (2000) Treatment of Gingival Hyperpigmentation for Esthetic purposes by Nd: YAG laser: Report of 4 cases. J Periodontol 71(2): 315-321.

11. Lost C (1984) Depth of Alveolar Bone Dehiscences in Relation to Gingival Recessions. J Clin Periodontol 11(9): 583-589.

This work is licensed under Creative Commons Attribution 4.0 License DOI: 10.19080/CTBEB.2018.16.555949

\begin{tabular}{|l|}
\hline \multicolumn{1}{|c|}{ Your next submission with Juniper Publishers } \\
will reach you the below assets \\
- Quality Editorial service \\
- Swift Peer Review \\
- Reprints availability \\
- E-prints Service \\
- Manuscript Podcast for convenient understanding \\
- Global attainment for your research \\
- Manuscript accessibility in different formats \\
( Pdf, E-pub, Full Text, Audio) \\
- Unceasing customer service \\
Track the below URL for one-step submission \\
https://juniperpublishers.com/online-submission.php \\
\hline
\end{tabular}

